\title{
Myxobolus neurophilus: morphologic, histopathologic and molecular characterization
}

\author{
Lester Khoo ${ }^{1,6, *}$, Frederick A. Rommel ${ }^{2, \mp}$, Stephen A. Smith ${ }^{3}$, Matt J. Griffin ${ }^{4}$, \\ Linda M. Pote ${ }^{5}$ \\ ${ }^{1}$ University of Pennsylvania, School of Veterinary Medicine, Kennett Square, Pennsylvania 19348, USA \\ ${ }^{2}$ Pennsylvania Veterinary Laboratory, 2305 Cameron Street, Harrisburg, Pennsylvania 17110, USA \\ ${ }^{3}$ Virginia-Maryland Regional College of Veterinary Medicine, Virginia Tech, Duck Pond Drive, Blacksburg, Virginia 24061, USA \\ ${ }^{4}$ Mississippi State University, College of Veterinary Medicine, PO Box 197, Stoneville, Mississippi 38776, USA \\ ${ }^{5}$ Mississippi State University, College of Veterinary Medicine, PO Box 6100, Mississippi State, Mississippi 39762, USA \\ ${ }^{6}$ Present address: Mississippi State University, College of Veterinary Medicine, PO Box 197, Stoneville, Mississippi 38776, USA
}

\begin{abstract}
Archived tissues from affected yellow perch Perca flavescens, as well as fresh submissions of juvenile yellow perch, walleye, fathead minnows, golden shiners and smallmouth bass cultured in the same pond or from a shared water source were examined for the presence of Мухоbolus neurophilus. Archived tissues were sectioned and stained with hematoxylin and eosin or with Giemsa, revealing myxozoan spores consistent with $M$. neurophilus. The myxospores were found beneath the ependymal lining of the central canal of the brain or free within the stratum periventriculare, with minimal or no inflammation. Unstained and stained (Wright Giemsa or Lugol's iodine) touch impressions of the brains from fresh submissions of all 5 fish species revealed similar myxozoan spores only in the brains of yellow perch. These were Giemsa-positive, with no iodinophilous vacuoles evident. Portions of the affected brains were fixed in neutral buffered $10 \%$ formalin and sectioned for histology. Pseudocysts containing myxospores were only evident in sections of the brains and spinal cords of yellow perch. Mild mononuclear meningoencephalitis was present when myxospores appeared outside of the pseudocysts. Brains fixed in $5 \%$ gluteraldehyde for scanning electron microscopic examination revealed pyriform myxospores with a smooth capsular surface. Sequencing and phylogenetic analysis of the 18S small subunit ribosomal DNA gene placed the organism within the family Myxobolidae, with no direct matches to sequences available via GenBank. Aquatic annelids from sediment obtained from the affected pond were negative for actinospores.
\end{abstract}

KEY WORDS: Yellow perch $\cdot$ Myxobolus neurophilus $\cdot$ Myxozoan

\section{INTRODUCTION}

Several Myxobolus species are known to infect the brains of fish (Table 1). To date, only M. aureatus and $M$. neurophilus have been reported from yellow perch Perca flavescens. M. aureatus is reported to also infect the gastrointestinal tract and swim bladder of yellow perch (Li \& Desser 1985), whereas M. neurophilus is limited to the central nervous system. Guilford (1963) observed M. neurophilus in the brains of feral yellow perch collected from Lake Michigan. These affected fish did not survive well in captivity, with several displaying neurological signs when the aquaria water was disturbed. Since that first description, relatively little has been added to the body of knowledge on this parasite.

Although a significant portion of the yellow perch industry in the United States is dependent on capture fisheries, there is a small but growing component of the industry that is based on cultured fish using ponds, 
Table 1. Myxobolus spp. Species reported to infect the nervous (brain) tissue of fishes. Sources: ${ }^{1}$ Bahri et al. (2003), ${ }^{2}$ Davies (2007), ${ }^{3}$ Eiras et al. (2005), ${ }^{4}$ Guilford (1963), ${ }^{5}$ Hogge et al. (2008), ${ }^{6}$ Hoffman (1999), ${ }^{7}$ Hoshina (1952), ${ }^{8}$ Levsen et al. (2004), ${ }^{9} \mathrm{Li} \&$ Desser (1985), ${ }^{10}$ Lom et al. (2006), ${ }^{11}$ McDonald \& Margolis (1995), ${ }^{12}$ Urawa \& Awakura (1994)

\begin{tabular}{|c|c|}
\hline Species & Host \\
\hline M. acanthogobi & Acanthogobius flavimanus ${ }^{7}$ \\
\hline M. africanus & Hepsetus odoe 3 \\
\hline M. arcticus & $\begin{array}{l}\text { Oncorhynchus keta }{ }^{12}, \\
\text { O. kisutch }^{6}, \text { O. masou }^{12}, \\
\text { O. nerka }{ }^{3,11}, \text { Salvelinus leuco- } \\
\text { maenis }^{12}, \text { S. malma }{ }^{6}, \text { S. neva } \\
\text { Thymallus sp. }\end{array}$ \\
\hline M. argenteus & Notemigonus crysoleucas ${ }^{11}$ \\
\hline M. aureatus & Perca flavescens ${ }^{11}$ \\
\hline M. balantiocheilli & Balantiocheilos melanopterus ${ }^{8}$ \\
\hline M. bilineatum & Fundulus heteroclitus ${ }^{3}$ \\
\hline M. buri & Seriola quniqueradiata ${ }^{3}$ \\
\hline M. cephalus & Mugil cephalus ${ }^{3}$ \\
\hline M. cerebralis & $\begin{array}{l}\text { Accidental site presumed in } \\
\text { salmonids }^{6}\end{array}$ \\
\hline M. confirmatus & Acanthorhodeus asmussi $i^{3}$ \\
\hline M. cotti & Cottus gobio ${ }^{3}$ \\
\hline M. cybinae & Phoxinus phoxinus ${ }^{3}$ \\
\hline M. cyprinicola & Lepomis gibbosus $^{11}$ \\
\hline M. drjagnini & Hypophthalmichthys molitrix ${ }^{6}$ \\
\hline M. encephalicus & Cyprinus carpio \\
\hline $\begin{array}{l}\text { M. fanthami } \\
\quad \text { (syn. M. grandis) }\end{array}$ & $\begin{array}{l}\text { Luxilis (Notropis) cornutus }{ }^{9,11} \\
\text { Notropis hudsonius }^{11}\end{array}$ \\
\hline M. farionis & Salmo trutta $f$. fario ${ }^{3}$ \\
\hline M. filamentosus & Puntius filamentosus ${ }^{3}$ \\
\hline M. hendricksoni & Pimephales promelas ${ }^{3}$ \\
\hline M. heterolepis & Notropis heterolepis ${ }^{10}$ \\
\hline M. hubeiensis & Saurogobio dabryi ${ }^{3}$ \\
\hline M. inaequus & Eigemannia viriscens ${ }^{3}$ \\
\hline M. jiroveci & Cottus gobio ${ }^{10}$ \\
\hline M. kisutchi & Oncorhynchus tshawytscha ${ }^{6}$ \\
\hline M. lairdi & Coryphaenoides rupestris ${ }^{3}$ \\
\hline M. muelleri & $\begin{array}{l}\text { Liza ramada }{ }^{1}, \text { Leuciscus } \\
\text { cephalus }^{2}, \text { L. leuciscus }^{2}, \\
\text { Rutilus rutilus }^{2}\end{array}$ \\
\hline M. neurotropus & Oncorhynchus mykiss ${ }^{5}$, O. clarki \\
\hline M. neurobius ${ }^{\mathrm{a}}$ & 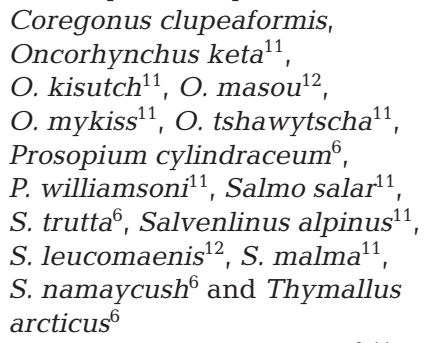 \\
\hline M. nemachili & $\begin{array}{l}\text { Luxilis (Notropis) cornutus }{ }^{9,11} \\
\text { Notropis heterolepis }\end{array}$ \\
\hline M. neurophilus & $\begin{array}{l}\text { Etheostoma nigrum }{ }^{5}, \text { Perca } \\
\text { flavescens }^{5}\end{array}$ \\
\hline M. notropis & $\begin{array}{l}\text { Luxilis (Notropis) cornutus }{ }^{9,11} \\
\text { Notemigonus crysoleucas }\end{array}$ \\
\hline M. schuberti & Luxilis (Notropis) cornutus ${ }^{9,11}$ \\
\hline
\end{tabular}

intensive recirculation systems, or a combination of both. A dwindling number of wild stocks has resulted in an increasing number of regulations limiting commercial fisheries. However, demand for the fish has remained high despite the declining number of wild fish, which means a greater dependence on cultured fish. It is therefore important to examine and understand diseases that could impact this growing segment of the aquaculture industry.

The goal of the present project was to gain a better understanding of this parasite by, further elucidating its morphology and lesions, determining the range of its host and utilizing molecular methods to ascertain its identity.

\section{MATERIALS AND METHODS}

Archival tissues. Tissues were obtained from fish (over the course of $2 \mathrm{yr}, 1999$ to 2000) brought into recirculation systems after purchase from a midwestern producer, originating from several states (Rommel 2001). These fingerlings had been raised in earthen ponds prior to their placement in recirculating systems, where, upon introduction, these fish showed signs of hyperexcitability that progressed to lethargy and drifting with the water flow. Increased levels ( 3\%) of mortalities occurred approximately 3 to 5 mo postintroduction to the recirculating systems, with cumulative mortalities of $\sim 50 \%$ recorded in the $2 \mathrm{yr}$ period. Affected fish were submitted to the Pennsylvania Animal Diagnostic Laboratory System (PADLS) over several months. Multiple gross and postmortem examinations were unremarkable, except for one that revealed Columnaris disease, which was resolved with antibiotic treatments. Viral isolations were also negative. Microscopic examination of tissues revealed large clusters of spores beneath the ependymal lining of the central canal of the brain or infiltrating the white matter of the optic lobes with little or no inflammatory response. The parasite was tentatively diagnosed as Myxobolus neurophilus based on morphology and myxospore location. Original glass slides of fish tissues (hematoxylin and eosin [H\&E] stained) from this case were reviewed. In addition, new slides were cut from all archived paraffin tissue blocks of this case that contained neural tissue. These slides were sectioned at $4 \mu \mathrm{m}$, stained either with H\&E or Giemsa and examined under a light microscope.

Fresh tissues. As a result of several diagnostic cases of yellow perch Perca flavescens exhibiting neurological signs and having parasitic cysts in the brain, yellow perch fingerlings obtained from the same producer were shipped to 2 locations in the fall of 2003. One sample of 50 fish was shipped to the Virginia-Mary- 
land Regional College of Veterinary Medicine, where 10 fish were evaluated by histopathology. The remaining fish were maintained in a 567 l, closed-recirculation system at $20^{\circ} \mathrm{C}$, with water-quality parameters within acceptable aquaculture standards; they were fed a commercial pelleted diet (Zeigler Bros). The fish were held for approximately 1 yr before being euthanized for histopathologic examination.

Another group of 50 fish were shipped to the diagnostic laboratory at the University of Pennsylvania along with 10 each of the following: walleye Stizostedion vitreum fingerlings, smallmouth bass Micropterus dolomineu fingerlings, golden shiners Notemigonus crysoleucas and fathead minnows Pimephales promelas. These fish were in the same earthen pond as the yellow perch or had shared the same water source. All fish were approximately 2.0 to $4.0 \mathrm{~cm}$ in length, except for the walleye, which were larger ( $6.0 \mathrm{~cm}$ in length). None of the fish exhibited neurological signs. All 90 fish were euthanized utilizing MS-222 (250 $\mathrm{mg} \mathrm{l}^{-1}$ ) (Tricaine-S, Western Chemical). The brains of the first 25 yellow perch and 5 brains from each of the other 4 species of fish were removed and bisected (cross-sectioned), and touch impressions were made on clean glass slides. A drop of sterile saline was placed on some of the unstained slides, covered with a loose coverslip and examined under the light microscope. The other slides were air dried and stained with Romanosky type stain (modified Wright-GiemsaFisher Hema 3, Fisher Scientific), while a smaller number of yellow perch brain-touch impressions were stained with Lugol's iodine and examined under a light microscope. The brains and carcasses of fish used for touch impressions, as well as the carcasses of the remaining fish, were fixed in neutral buffered $10 \%$ formalin. Those that did not have their brains removed for touch impressions had their craniums pried open with ronguers to allow proper fixation of the neural tissue. The fixed tissue was later trimmed and, processed, and $4 \mu \mathrm{m}$ sections were cut and stained with either H\&E or Giemsa for examination under a light microscope.

Yellow perch held in the recirculation tanks for $1 \mathrm{yr}$ failed to thrive and were only slightly larger than when they first arrived in Virginia. The tissues from these fish were handled similarly to the fresh tissues previously described. The only difference was that the tissues were decalcified utilizing Cal-EX (Fisher Scientific, for $\sim 5 \mathrm{~min}$ ) until pliable under digital pressure to allow for crosssections to be cut for histological examination.

Electron microscopy. Myxospores were dissociated from fresh brain tissue by blunt dissection, quickly rinsed in cold phosphate-buffered saline (PBS), and placed in electron microscope fixative $(5 \%$ gluteraldehyde, $4.4 \%$ formalin, and $2.75 \%$ picric acid in $0.05 \mathrm{M}$ Na cacodylate) overnight. The sample was then passed through a Nuclepore polycarbonate filter $(13 \mathrm{~mm}$, $0.2 \mu \mathrm{m})$, where the myxospores became deposited on the filter material. The filter was then rinsed in $0.1 \mathrm{M}$ $\mathrm{Na}$ cacodylate buffer and post-fixed with $1 \% \mathrm{OsO}_{4}$ in $0.1 \mathrm{M} \mathrm{Na}$ cacodylate buffer for $1 \mathrm{~h}$. The filter was again rinsed with $0.1 \mathrm{M} \mathrm{Na}$ cacodylate buffer and processed through a graded ethanol series to $100 \%$ ethanol. The filter was then critical point dried, sputter-coated with a $140 \AA$ Alayer of gold, mounted on a stud and viewed with a Zeiss EV040 scanning electron microscope.

Analysis of sediment samples. A subsample of the sediment was collected from the earthen pond at the same time the fish samples were collected; it was placed in a plastic bag with air and shipped overnight to the College of Veterinary Medicine Parasitology Laboratory at Mississippi State University. The sample was gently screened through a copper mesh screen (aperture $300 \mu \mathrm{m}$, Fisher Scientific Company) using dechlorinated water. Using techniques previously described (Yokoyama et al. 1991, Pote et al. 1994), the screened contents were examined under a dissecting microscope $(12 \times$ magnification). All live aquatic annelids were removed using a hooked metal probe, individually placed into 96-well plates (Becton Dickinson and Co.) and covered with approximately $0.1 \mathrm{ml}$ of sodium-free sterile spring water (Walmart; spring source: McNair Springs, Magee, Mississippi). Individual worms were examined for shedding of actinospores every $24 \mathrm{~h}$ for at least $7 \mathrm{~d}$ using a dissecting microscope $(12 \times$ to $40 \times$ magnification). Water was removed daily from all wells and replaced with fresh sterile water. The water from the wells in which the water appeared turbid or to contain particulate matter was further examined microscopically (200× magnification) on a glass slide without a coverslip for the presence of actinospores.

Molecular analysis. The myxozoan cysts were identified microscopically, excised by sharp dissection, placed in a $1.5 \mathrm{ml}$ microcentrifuge tube of nucleasefree water and mechanically ruptured by pipetting. The myxospores were concentrated by centrifugation at $20000 \times g$ for $20 \mathrm{~min}$, and all but $100 \mu \mathrm{l}$ of centrifugate was removed by transfer pipette. The centrifugate was then dried by vacuum centrifugation and microwaved on the high setting for $1 \mathrm{~min}$ in an $800 \mathrm{~W}$ microwave. Samples were then resuspended in $600 \mu \mathrm{l}$ of Puregene Cell Lysis Solution (Gentra) prior to $10 \mathrm{~min}$ incubation at $95^{\circ} \mathrm{C}$. Following initial lysis, $3 \mu \mathrm{l}$ of Proteinase K (20 mg ml $\mathrm{m}^{-1}$ ) was added to the lysate, mixed by inversion and incubated at $56^{\circ} \mathrm{C}$ overnight. The remainder of the isolation was carried out according to the manufacturer's suggested protocol. The purified genomic DNA was then suspended in $30 \mu \mathrm{l}$ of Puregene DNA hydration solution (10 mM Tris, $1 \mathrm{mM}$ EDTA, pH 7.0 to 8.0 ). 
18S SSU rDNA gene amplification. The $18 \mathrm{~S}$ small subunit (SSU) ribosomal DNA (rDNA) gene was first amplified with the universal eukaryotic primers ERIB1 and ERIB10 (Barta et al. 1997, Fiala 2006) (Table 2). Nested polymerase chain reactions (PCR) were carried out in duplicate using the generic myxozoan primer sets H2 and H9 described by Hanson et al. (2001), MyxospecF and MyxospecR from Fiala (2006) and Genmyxo3 and Genmyxo4 from Griffin et al. (2008) (Table 2). The initial $25 \mu \mathrm{l}$ PCR reaction mixture contained $2.5 \mu$ of TaKaRa Taq Hot Start Version 10× PCR buffer (TaKaRa Bio), $5 \mathrm{nmol}$ of each dNTP, $10 \mathrm{pmol}$ of each primer, $0.625 \mathrm{U}$ of TaKaRa Taq Hot Start Taq polymerase, $13.75 \mu \mathrm{l}$ of nuclease-free $\mathrm{H}_{2} \mathrm{O}$ and $2 \mu \mathrm{l}$ of DNA template. The reaction mixture was cycled on a PTC-100 thermal cycler with an initial denaturation step of $95^{\circ} \mathrm{C}$ for $10 \mathrm{~min}$ followed by 30 cycles of $95^{\circ} \mathrm{C}$ for $1 \mathrm{~min}, 48^{\circ} \mathrm{C}$ for $1 \mathrm{~min}, 72^{\circ} \mathrm{C}$ for $2 \mathrm{~min}$, and a final extension step of $72^{\circ} \mathrm{C}$ for $10 \mathrm{~min}$. One microliter of PCR product from the initial reaction was used in nested PCR with the following primer combinations; H2/H9, MyxospecF/MyxospecR, Genmyxo3/H2 and Genmyxo4/H2. All reaction components remained the same except $14.75 \mu \mathrm{l}$ nuclease-free water was used to bring the reaction volume to $25 \mu \mathrm{l}$ and the annealing temperature was $52^{\circ} \mathrm{C}$ instead of $48^{\circ} \mathrm{C}$. The PCR product was run on a $1.2 \%$ agarose gel and stained with Gelstar nucleic acid stain (Cambrex) to confirm the presence of DNA product.

Sequencing of PCR product. The PCR products were purified using a montage PCR centrifugal filter device (Millipore), resuspended in $20 \mu \mathrm{l}$ Puregene DNA hydration solution and quantified using a Nanodrop spectrophotometer and the accompanying software (Nanodrop Technologies). The product was then sequenced directly 3 times in each direction by dideoxy chain termination sequencing (Sanger et al. 1977) with an ABI prism dye termination cycle sequencing kit (Applied Biosystems) using approximately $40 \mathrm{ng}$ of template per reaction. The products were purified using Centri-Sep Spin columns (Prince-

Table 2. Referenced primer sequences utilized in sequencing of the $18 \mathrm{~S}$ small subunit ribosomal DNA gene

\begin{tabular}{|lll|}
\hline Designation & \multicolumn{1}{c|}{ Sequence } & \multicolumn{1}{c|}{ Source } \\
\hline H2 & CGACTTTTACTTCCTCGAAATTGC & Hanson et al. (2001) \\
H9 & TTACCTGGTCCGGACATCAA & Hanson et al. (2001) \\
MysospecF & TTCTGCCCTATCAACTWGTTG & Fiala (2006) \\
MyxospecR & GGTTTCNCDGRGGGMCCAAC & Fiala (2006) \\
Genmyxo3 & TGATTAAGAGGAGCGGTTGG & Griffin et al. (2008) \\
Genmyxo4 & GGATGTTGGTTCCGTATTGG & Griffin et al. (2008) \\
ERIB1 & ACCTGGTTGATCCTGCCAG & Barta et al. (1997) \\
ERIB10 & CCTCCGCAGGTTCACCTACGG & Barta et al. (1997) \\
\hline
\end{tabular}

ton Separations) and analyzed on an ABI Prism 310 genetic analyzer at the USDA-ARS Mid-South Area Genomics Laboratory in Stoneville, MS, USA. Excess dye terminators were removed by ethanol/EDTA precipitation as per the ABI protocol. The obtained sequence fragments were assembled into a contiguous sequence using the SeqMan utility of the Lasergene v. 7.2.1 software package (DNASTAR) using corresponding $\mathrm{ABI}$ chromatograms to clarify ambiguous bases.

Phylogenetic analysis. The obtained sequence was compared with similar sequences of described myxozoans using a BLAST (megablast) search for highly similar sequences of the National Center for Biotechnology Information's non-redundant nucleotide (nr/nt) database. Preliminary analysis (data not shown) included 75 of the most similar sequences (excluding duplicates) identified by the BLAST search. From this initial data set, the number of sequences was reduced to 25 , which included the most similar sequences from described myxozoans, as well as sequences from representative members of well-defined groups of closely related myxobolids. Ceratomyxa shasta (AF001579) was chosen as an outgroup to root the phylogenetic analysis.

Phylogenetic and molecular evolutionary analyses were conducted using the MEGA4 (Molecular Evolutionary Genetics Analysis, v. 4.0) software package (Tamura et al. 2007). The data were analyzed by maximum parsimony analysis (MP) using a close-neighborinterchange (CNI) Search Level 3 with the random addition of 100 trees. Minimum evolution (ME) distance analysis was also performed using a CNI Search Level 3, with evolutionary distances determined by maximum composite likelihood (Rzhetsky \& Nei 1992, Nei \& Kumar 2000). The initial tree for ME analysis was generated using the neighbor-joining algorithm with pair-wise gap deletion (Saitou \& Nei 1987, Tamura et al. 2004). Clade support for both analyses was assessed by bootstrapping (1000 replicates for ME; 100 replicates for MP) (Felsenstein 1985).

Sequence identities ( $\%$ similarity) to Myxobolus neurophilus were determined for the 15 most similar sequences identified by the BLAST (megablast) search. Sequences were aligned using the Clustal W utility of the MEGA4 software package (Tamura et al. 2007), and results were based on pair-wise analysis of the nucleotide sequences. The percent similarities between the M. neurophilus 18S SSU rDNA sequence and the 18S SSU rDNA sequences of these select myxozoans were determined. 


\section{RESULTS}

\section{Host range}

Of the 5 species of fish examined, only yellow perch Perca flavescens appeared to be infected by the myxozoan parasite Myxobolus neurophilus. Myxospores with morphology consistent with that described below were seen on touch impressions of the brains, as well as in the central nervous system tissue of these fish on histological examination. Thirty-six of the 50 yellow perch sent to Pennsylvania were affected.

Although all live aquatic annelids from the sediment sample were examined, none were found to be shedding actinospores over the $7 \mathrm{~d}$ period. As such, species identification on individual worms was not attempted.

\section{Spore morphology and associated pathology}

Numerous, bivalvular, ellipsoid to ovoid spores were evident on the touch impressions of the yellow perch brains. These myxospores appeared lightly refractile

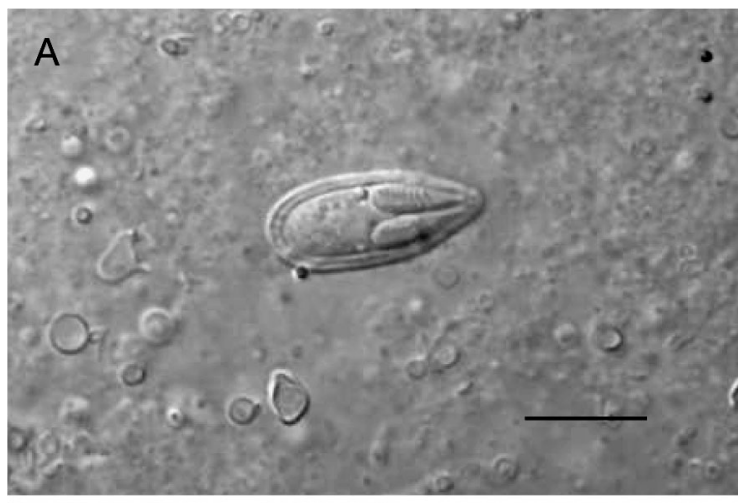

B

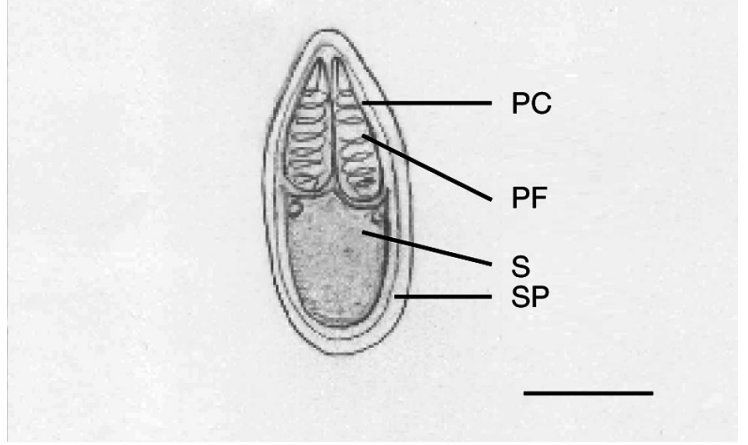

Fig. 1. Myxobolus neurophilus. (A) Wet mount of touch impression of yellow perch Perca flavescens brain with $M$. neurophilus, using a Nomarski filter. Scale bar $\approx 10 \mu \mathrm{m}$. (B) Schematic of the frontal view of a typical $M$. neurophilus myxospore; PC: polar capsule; PF: polar filament; S: sporoplasm; SP: spore capsule. Scale bar $\approx 5 \mu \mathrm{m}$ (with Normaski filters) and measured approximately $16.3 \pm 0.43 \mu \mathrm{m}(\mathrm{n}=20$; range 15.4 to $16.8 \mu \mathrm{m})$ in length and approximately $6.5 \pm 0.40 \mu \mathrm{m}(\mathrm{n}=20$; range 5.6 to $7.0 \mu \mathrm{m}$ ) in width (Fig. 1). Each myxospore contained 2 pyriform, mildly dissymmetrical, polar capsules that occupied approximately half the length of the myxospore, with the basal, more rounded half filled with a single, binucleate sporoplasm. There were at least 7 turns per polar filament coil.

No iodinophilous vacuole was evident on staining with Lugol's iodine. Myxospores did not pick up the iodine stain although their outlines were made more distinct from the small number of inflammatory cells and small amount of neural tissue that was also on the slides.

The modified Wright-Giemsa stain provided a much better differentiation of the myxospores from the surrounding milieu, as the polar capsules were stained dark bluish purple, while the capsular surface was blue and the sporoplasm clear to light blue. The number of rings of the coiled filaments in the polar capsule was not evident using the modified Wright-Giemsa stain because of the diffuse intense staining of the polar capsule and because most myxospores had discharged their polar filaments, which were about 5 to 10 times the length of the myxospores. The myxospores also lacked a caudal process (Fig. 2).

The scanning electron micrographs (SEM) confirmed the pyriform morophology of the myxospores (Fig. 3) characterized by a bluntly pointed anterior extremity and a more broadly rounded posterior. The SEMs also revealed that the myxospores had a relatively smooth valvular surface, with no other prominent morphological features.

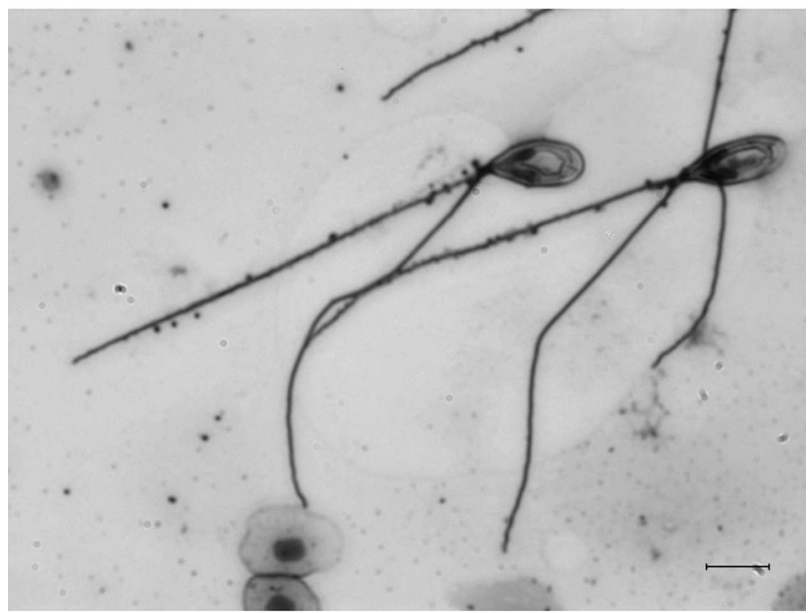

Fig. 2. Myxobolus neurophilus. Wet mount of myxospores from yellow perch Perca flavescens brain. Note the lack of a caudal process. Modified Wright-Giemsa stain. Scale bar $\approx$ $10 \mu \mathrm{m}$ 
The myxospores were difficult to distinguish on H\&E sections of the archived tissue. There was some evidence of their presence by the slightly expanded portions of the affected neural tissue as well as the faint, brown refractile quality of the myxospores. They were easily identified on Giemsa-stained sections (Fig. 4), and most of the myxospores did not appear to be in pseudocysts (non-epithelial-lined cyst-like structures) in these tissues, but were within the stratum periventriculare subjacent to the ependymal lining and sometimes extending to the menix primitiva (meninges). There was a minimal to mild mononuclear inflammatory component.

In the freshly collected tissue, staining characteristics of myxospores were similar to the archived tissues. The discrete aggregates of developing myxospores or plasmodia were most often seen in sections of the mesencephalon and diencephalon. These

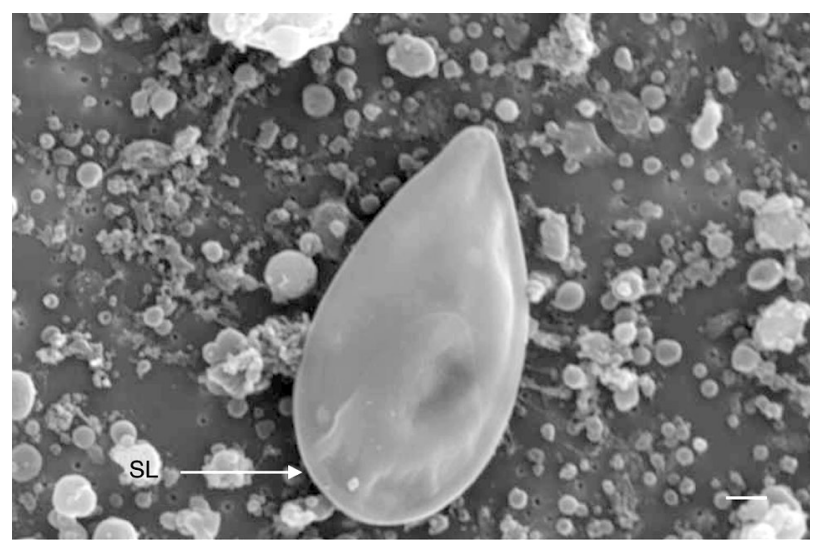

Fig. 3. Myxobolus neurophilus. Scanning electron micrograph of a myxospore. SL: suture line. Scale bar $\approx 1 \mu \mathrm{m}$

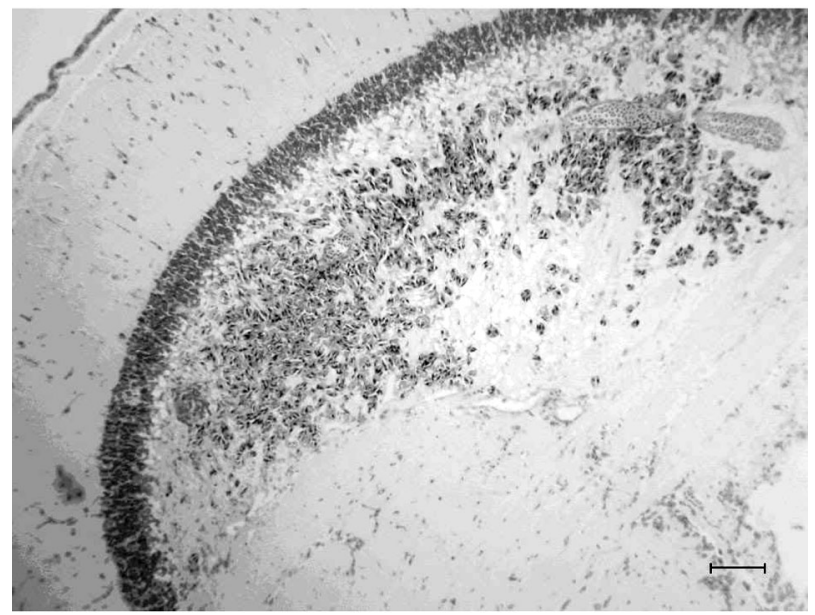

Fig. 4. Myxobolus neurophilus. Cross-section of yellow perch Perca flavescens brain (archived tissue), with loose myxospores in the optic tectum (Giemsa). Scale bar $\approx 50 \mu \mathrm{m}$ space-occupying aggregates were in cyst-like structures that extended into and partially occluded the ventricular lumina within the brain or compressed the surrounding white matter (Figs. 5 \& 6). These clusters of myxospores were often surrounded by a pink hyaline lining on Giemsa staining. A mild mononuclear meningoencephalitis was evident only if the myxospores were free within the white matter and not within these clusters. Smaller clusters of these myxospores were also found within the spinal cord, and these sometimes also contained globular to elongate $(\sim 6.0 \mu \mathrm{m}$ in width and up to $20 \mu \mathrm{m}$ in length) cells (presporogenic stages-presumptive) that were stained light blue and often had multiple nuclei on Giemsa staining (Figs. 7 \& 8). Most fish that had spinal cord clusters also had clusters in the brain.

In the long-term study fish (fish held in the recirculating system in Virginia), the fish showed little growth. These fish had histopathologic changes similar to the fresh samples, except the presumptive presporogenic stages stained a light pink rather than blue on Giemsa.

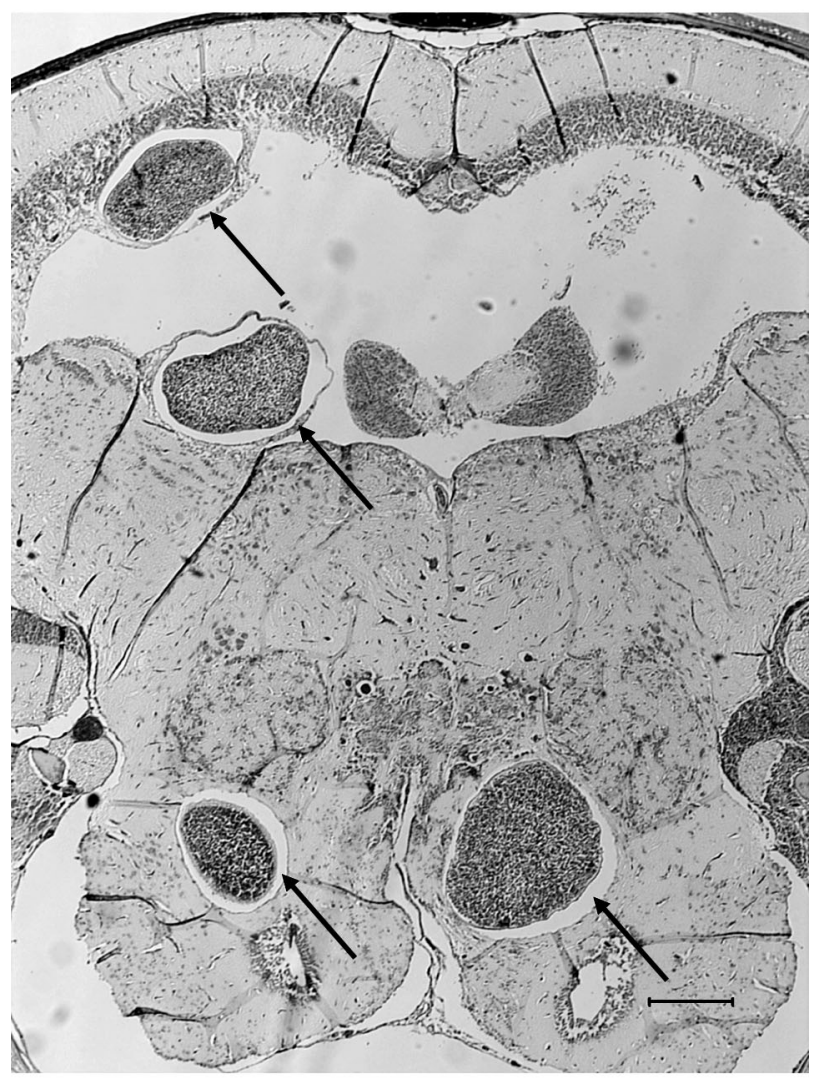

Fig. 5. Myxobolus neurophilus. Cross-section of yellow perch Perca flavescens brain (fresh submission). Arrows indicate pseudocysts containing numerous myxospores (Giemsa).

Scale bar $\approx 250 \mu \mathrm{m}$ 


\section{Molecular results}

Phylogenetic analysis of the $1688 \mathrm{bp}$ sequence of the 18S SSU rDNA gene clearly distinguished this isolate from all other Myxobolus species sequenced to date. The obtained sequence was $<93 \%$ similar to any myxozoan 18S SSU rDNA sequences available from GenBank (Table 3). Both methods of phylogenetic inference placed the case isolate within a group of Myxobolus species (100\% bootstrap support by MP; $96 \%$ support by ME) containing $M$. diaphanus isolated from various tissues of the banded killifish Fundulus diaphanus and $M$. procerus from the muscles of trout perch Percopsis omiscomaycus. The phylograms generated from MP and ME analyses are shown in Figs. 9 \& 10 , respectively.

\section{DISCUSSION}

Myxobolus neurophilus was first described in the mid-brains of yellow perch Perca flavescens and Johnny darter Etheostoma nigrum from Green Bay,

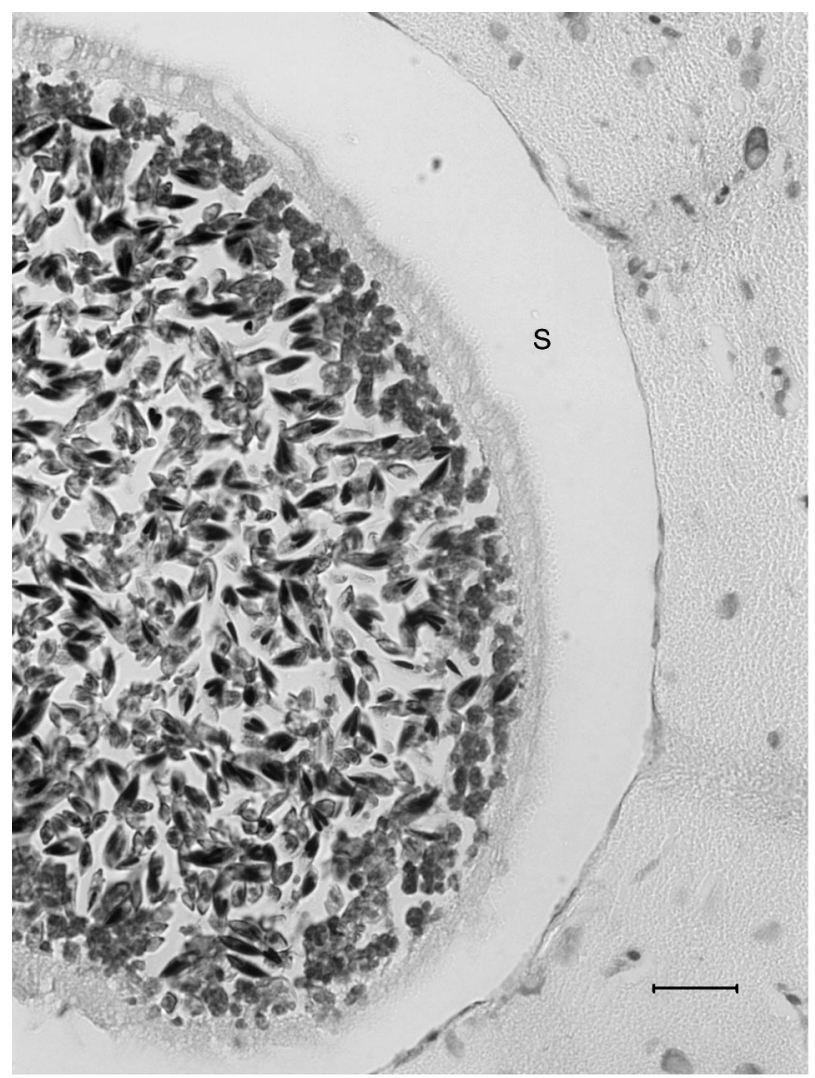

Fig. 6. Myxobolus neurophilus. Higher magnification of pseudocyst in Fig. 5. The space (S) between the pseudocyst and the surrounding neural tissue is thought to be an artifact of fixation and processing (Giemsa). Scale bar $\approx 50 \mu \mathrm{m}$
WI, USA (Lake Michigan) (Guilford 1963). This histiozoic myxozoan parasite was originally classified within the Myxosoma genus (i.e. Myxosoma neurophilia) perhaps because of the lack of iodinophilous vacuoles (Hoffman 1999). However, Lom \& Noble (1984) revised the classification of the Myxosoma genus to be synonymous with Myxobolus; hence, this parasite is currently referred to as Myxobolus neurophilus (Landsberg \& Lom 1991).

The second report of this parasite was by Dzulinksy et al. (1994), which provided details of development of the infection and parasite, and also the range of this parasite, which extends east to Nova Scotia. These affected fish, like those in the original description, were feral fish. Muzzall (1995) provided the first description of this parasite in pond-reared yellow perch.

Easy (2004) used morphological and molecular techniques to discriminate between myxospores collected from yellow perch and the Johnny darter. Based mainly on molecular data and to a much lesser extent morphology, Easy (2004) concluded that Myxobolus neurophilus is only in yellow perch and the myxozoan

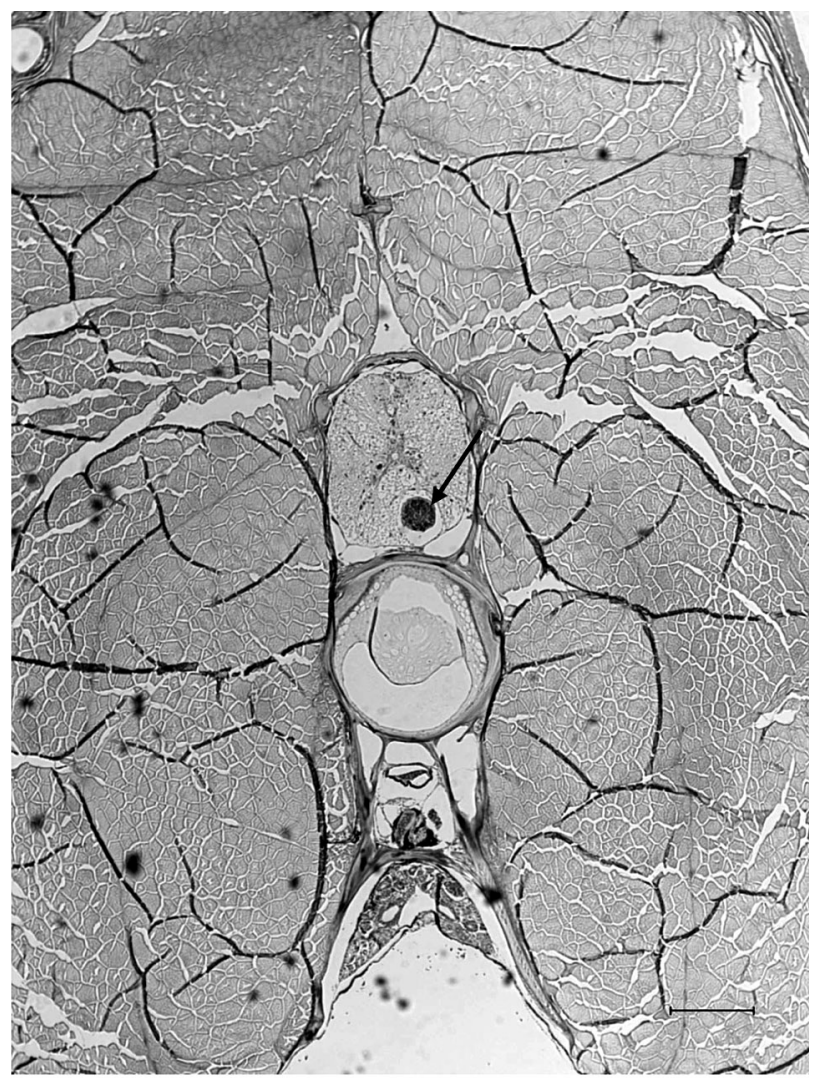

Fig. 7. Myxobolus neurophilus. Cross-section through body of a juvenile yellow perch Perca flavescens. Arrow indicates pseudocyst in spinal cord (Giemsa). Scale bar $\approx$ $250 \mu \mathrm{m}$ 


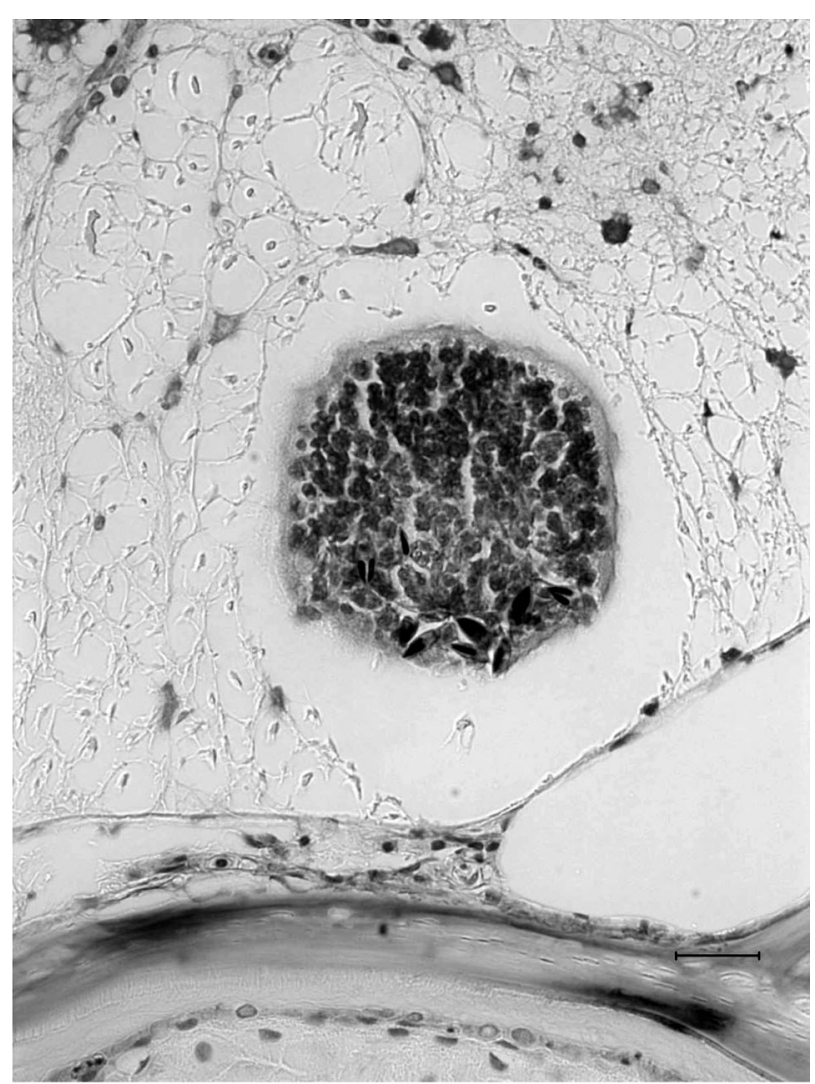

Fig. 8. Myxobolus neurophilus. Higher magnification of spinal cord pseudocyst in Fig. 7. Note the lack of an inflammatory infiltrate (Giemsa). Scale bar $\approx 25 \mu \mathrm{m}$

spores in the Johnny darter most closely resemble Myxobolus procerus, but most likely represent a previously undescribed Myxobolus sp.

The original description of the case for the archival tissue was by Rommel (2001). The archival tissue was reexamined because of the differences in clinical presentation from the fresh submission. There were neurological signs with the earlier case and no clinical signs with the fresh submission. The myxospores were mainly loose within the neural tissue for the archived material rather than enclosed in pseudocysts as seen with the fresh specimens, and the minimal to mild inflammatory response was most often associated only with the loose myxospores. This difference may reflect the maturity of the infection and the myxospore as suggested by Dzulinksy et al. (1994), i.e. the termination of sporogenesis is highlighted by the rupture of the plasmodium and release of the myxospores into the periventricular layer. In the present study, wet mounts and histological sections of fish held for $1 \mathrm{yr}$, as well as those examined when first submitted, demonstrated similar histopathological lesions and myxospore morphology, except for some tinctorial differences, which
Table 3. Identity of Myxobolus neurophilus small subunit ribosomal DNA (GenBank Accession Number FJ468489) to similar myxozoan sequences. Sequence ambiguities were removed prior to calculation

\begin{tabular}{|lrc|}
\hline Species & $\begin{array}{c}\text { DNA sequence } \\
\text { identity to } \\
\text { M. neurophilus }\end{array}$ & $\begin{array}{c}\text { GenBank } \\
\text { Acc. No. }\end{array}$ \\
\hline Myxobolus procerus & $685 / 742(92.3 \%)$ & AY665296 \\
M. diaphanus & $794 / 886(89.6 \%)$ & AY950664 \\
M. dauodi & $849 / 993(85.5 \%)$ & EU643625 \\
Henneguya adiposa & $1430 / 1702(84.0 \%)$ & EU492929 \\
H. exilis & $1427 / 1698(84.0 \%)$ & AF021881 \\
M. episquamalis & $1363 / 1627(83.8 \%)$ & AY129312 \\
H. ictaluri & $1417 / 1696(83.6 \%)$ & AF195510 \\
H. lesteri & $1362 / 1649(82.6 \%)$ & AF306794 \\
M. bizerti & $1168 / 1424(82.0 \%)$ & AY129318 \\
H. gurleyi & $1391 / 1697(82.0 \%)$ & DQ673465 \\
M. exiguus & $1161 / 1421(81.7 \%)$ & AY129317 \\
H. sutherlandi & $1382 / 1693(81.6 \%)$ & EF191200 \\
H. akule & $1396 / 1714(81.5 \%)$ & EU016076 \\
M. ichkeulensis & $1158 / 1427(81.1 \%)$ & AY129315 \\
M. spinacurvatura & $1153 / 1423(81.0 \%)$ & AF378341 \\
\hline
\end{tabular}

were most likely due to the decalcification process. Perhaps the conditions under which the fish were held in the recirculating systems arrested the development of the parasite. It is difficult to comprehend why the compression of the neural tissue in the diencephalon and mesencephalon by the relatively large pseudocysts (approximately 0.5 to $1 \mathrm{~mm}$ in diameter) in the fresh submissions did not result in some neurological signs. These histopathological lesions are somewhat similar to Myxobolus hendricksoni infection in fathead minnows, where large portions of the brain (optic lobes, cerebellum, ventricles and meninges) are replaced by the parasite with minimal host response (Mitchell et al. 1985), although no rodlet cells were seen or have been described in $M$. neurophilus infections. These cases also highlight the neurotropic behavior of $M$. neurophilus as there was no microscopic evidence of this protozoan elsewhere in multiple cross-sections through the fish examined confirming the findings of Dzulinksy et al. (1994).

Myxospore morphology and measurements were within ranges described previously for this parasite (Guilford 1963, Dzulinksy et al. 1994, Easy 2004); however, the accompanying sequence data will aid in discriminating Myxobolus neurophilus from morphologically similar neurotrophic myxozoans. Although $M$. aureatus has been reported in yellow perch brains (Li \& Desser 1985), the myxospore morphology of this parasite differs from that of $M$. neurophilus. $M$. aureatus is shorter (12.4 to $13.5 \mu \mathrm{m}$ vs. 15.4 to $16.8 \mu \mathrm{m})$, wider (6.5 to $7.5 \mu \mathrm{m}$ vs. 5.6 to $7.0 \mu \mathrm{m})$ and has a more pronounced pyriform shape (a more pointed apical extremity and a more rounded base) compared to 
M. neurophilus (Cone et al. 2005, Eiras et al. 2005). Lom et al. (1992) also questioned the identification of $M$. aureatus in yellow perch as the report (Li \& Desser 1985) lacked both drawings and descriptions of the myxospores. Unfortunately, no known published sequence data are available for $M$. aureatus to provide a genetic comparison with $M$. neurophilus. Although host range, tissue specificity and myxospore morphology have been used in the past to classify the different Myxobolus species, molecular techniques have now been used to provide greater discrimination and con- firmation. Bahri et al. (2003) hypothesized that for particular Myxobolus species, the environment may in part determine differences in myxospore morphology, since they found differences in myxospores from diverse tissues in the same host. They concluded, however, that, if considered together, the host range, tissue specificity and myxospore morphology are useful criteria in identification of species. It is interesting to note that $M$. aureatus is also described to infect the fins of Notropis anogenus, the pugnose shiner (Eiras et al. 2005).

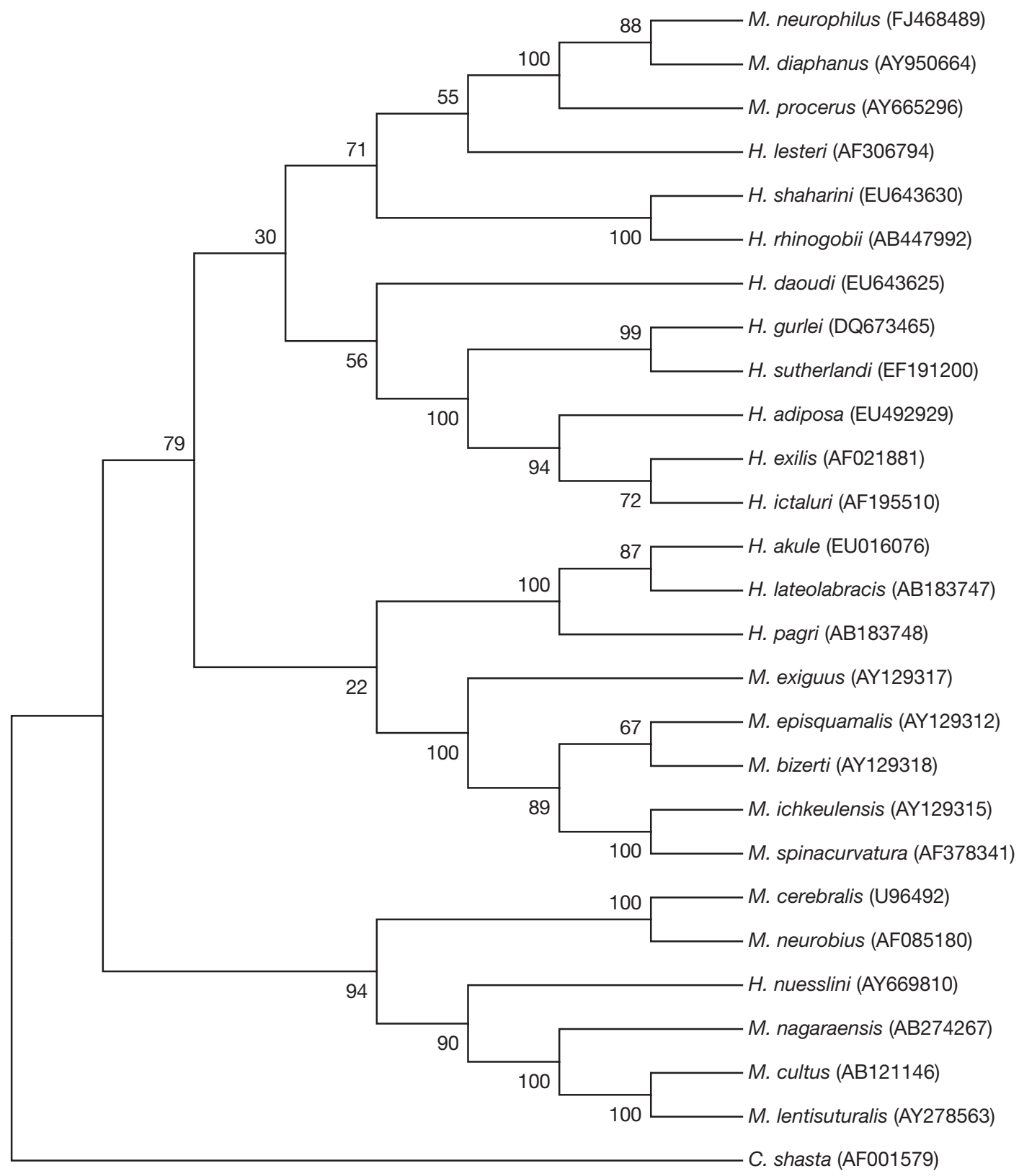

Fig. 9. Phylogenetic tree generated by maximum-parsimony analysis of the 18S SSU rDNA sequence of myxozoans, rooted at Ceratomyxa shasta. Numbers at nodes indicate bootstrap confidence values (100 replications). GenBank accession numbers are given in parentheses. M: Myxobolus; H: Henneguya 


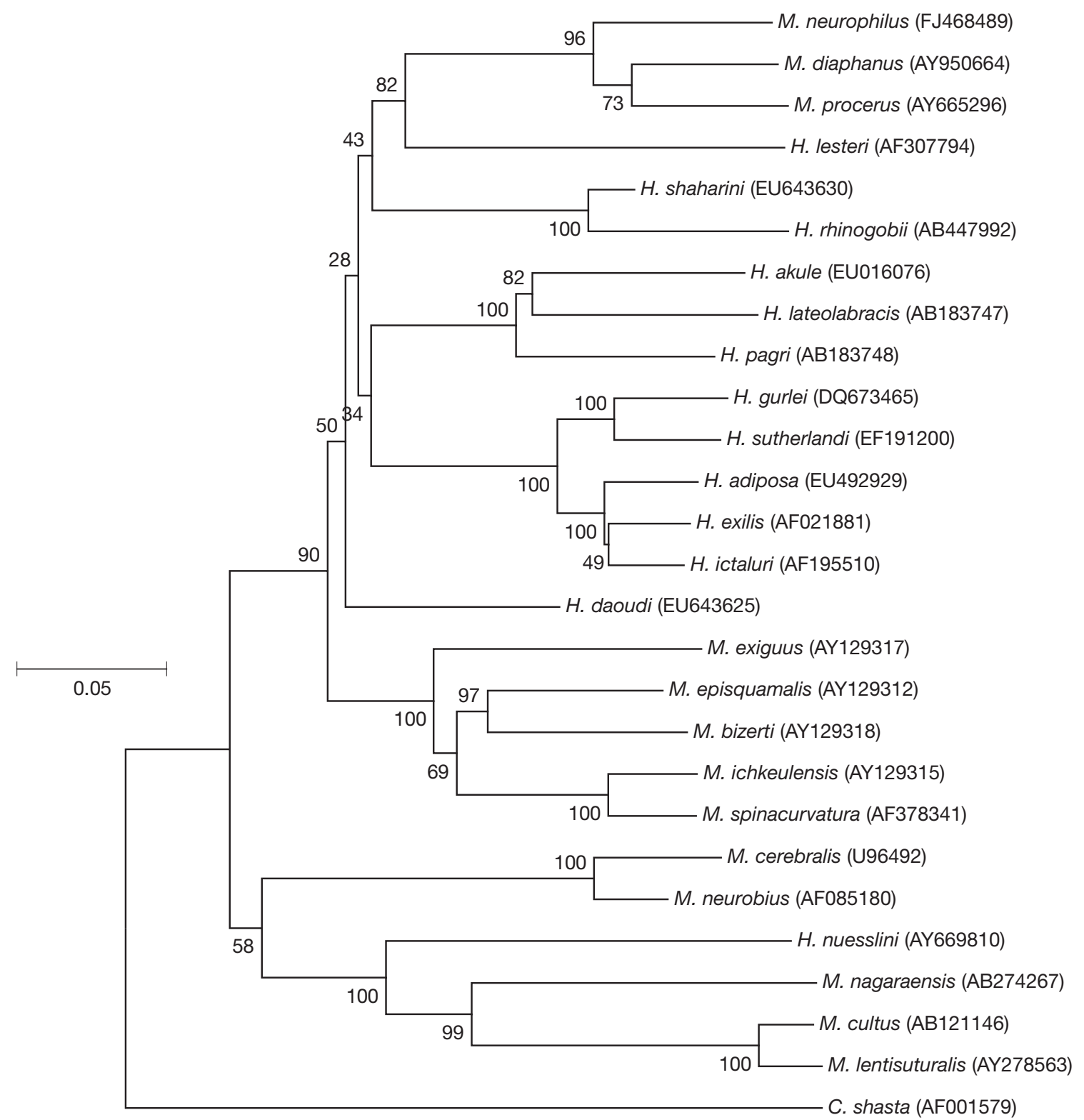

Fig. 10. Phylogenetic tree generated by minimum-evolution analysis of the 18S SSU rDNA sequence of myxozoans, rooted at Ceratomyха shasta. Numbers at nodes indicate bootstrap confidence values (1000 replications). GenBank accession numbers are given in parentheses. M: Myxobolus; H: Henneguya

In the present study, only yellow perch were infected, and this myxozoan parasite was limited to tissues of the central nervous system. No similar myxozoan parasite was evident in the neural tissue of walleye, fathead minnows, golden shiners, or smallmouth bass that were raised in the same pond or a shared water source. This confirms that thus far, Myxobolus neurophilus is only known to infect yellow perch. The pathology and the fact that this parasite is seen in both feral and cultured fish would indicate that this parasite can have a significant negative impact on the yellow perch industry. The determined genetic sequence not only allows for definitive identification of the parasite, but should aid in future work to investigate the different life stages and possible invertebrate host.

Acknowledgements. The authors thank B. Scheffler and F. Xiu of the USDA-ARS Mid-South Area Genomics Laboratory, Stoneville, MS, USA, for assistance in sequence analysis, and K. Lowe of the VMRCVM Ultrastructural Laboratory for prepa- 
ration of myxospores for SEM. This research was supported by the School of Veterinary Medicine, University of Pennsylvania, and the College of Veterinary Medicine, Mississippi State University, and Mississippi Agricultural and Forestry Experiment Station (MAFES), Mississippi State University. This is Journal Article No. J-11755 of Mississippi Agricultural and Forestry Experiment Station, Mississippi State University.

\section{LITERATURE CITED}

Bahri S, Andree KB, Hedrick RP (2003) Morphological and phylogenetic studies of marine Myxobolus spp. from mullet in Ichkeul Lake, Tunisia. J Eukaryot Microbiol 50: 463-470

Barta JR, Martin DS, Liberator PA, Dashkevicz M and others (1997) Phylogenetic relationships among eight Eimeria species infecting domestic fowl inferred using complete small subunit ribosomal DNA sequences. J Parasitol 83:262-271

> Cone DK, Yang J, Sun G, Easy R (2005) Taxonomy and molecular phylogeny of Myxobolus bibolus n. sp. (Myxozoa) parasitizing Notemigonus crysoleucas (Cyprinidae) in Algonquin Park, Ontario, Canada. Dis Aquat Org 66: 227-232

Davies EH (2007) Myxosporidian parasites from the fish of the River Lugg. J Eukaryot Microbiol 15:471-480

> Dzulinksy K, Cone DK, Faulkner GT, Cusack R (1994) Development of Myxobolus neurophilus (Guilford, 1963) (Myxosporea) in the brain of yellow perch (Perca flavescens) in Vinegar Lake, Nova Scotia. Can J Zool 72:1180-1185

Easy RH (2004) Taxonomy of selected species of Myxobolus (Myxozoa) from freshwater fishes in Canada; applications of light microscopy and molecular methods. MS thesis, St. Mary's University, Halifax, NS

Eiras JC, Molnár K, Lu TS (2005) Synopsis of the species Myxobolus Bütschli, 1882 (Myxozoa: Myxosporea: Myxobolidae). Syst Parasitol 61:1-46

Felsenstein J (1985) Confidence limits of phylogenies: an approach using the bootstrap. Evolution 39:783-791

Fiala I (2006) The phylogeny of Myxosporea (Myxozoa) based on small subunit ribosomal RNA gene analysis. Int J Parasitol 36:1521-1534

Griffin MJ, Wise DJ, Camus AC, Mauel MJ, Greenway TE, Pote LM (2008) A novel Henneguya sp. from channel catfish (Ictalurus punctatus) described by morphological, histological and molecular characterization. J Aquat Anim Health 20:127-135

Guilford HG (1963) New species of myxosporidia found in percid fishes from Green Bay (Lake Michigan). J Parasitol 49:474-478

Hanson LA, Lin D, Pote LM, Shivaji R (2001) Small subunit rRNA gene comparisons of four actinosporean species to establish a polymerase chain reaction test for the causative agent of proliferative gill disease in channel catfish. J Aquat Anim Health 13:117-123

Hoffman GL (1999) Parasites of North American freshwater fishes. Cornell University Press, Ithaca, NY

Hogge CI, Campbell MR, Johnson KA (2008) A new species of myxozoan (Myxosporea) from the brain and spinal cord of rainbow trout (Oncorhynchus mykiss) from Idaho. J Parasitol 94:218-222

Editorial responsibility: Sven Klimpel,

Düsseldorf, Germany
Hoshina T (1952) Notes on some myxosporidian parasites on fishes of Japan. J Tokyo Univ Fish 39:68-69

Landsberg JH, Lom J (1991) Taxonomy of the genera of the Myxobolus/Myxosoma group (Myxobolidae: Myxosporea), current listing of species and revision of synonyms. Syst Parasitol 18:165-186

$>$ Levsen A, Alvik T, Grotmol S (2004) Neurological symptoms in tricolor sharkminnow Balantiocheilos melanopterus associated with Myxobolus balantiocheili n. sp. infecting the central nervous system. Dis Aquat Org 59:135-140

$>$ Li L, Desser SS (1985) The protozoan parasites of fish from two lakes in Algonquin Park, Ontario, Canada. Can J Zool 63:1846-1858

Lom J, Noble E (1984) Revised classification of the class of Myxosporea Bütschili, 1881. Folia Parasitol 31: 193-205

Lom J, Dyková I, Horner RW, Hoffman GL, Durham L (1992) Comments on the identity of Myxobolus aureatus. J Aquat Anim Health 4:129-134

Lom J, Feist SW, Dyková I, Keper T (2006) Brain myxoboliasis of bullhead, Cottus gobio L., due to Myxobolus jiroveci sp. nov.: light and electron microscope observations. J Fish Dis 21:15-27

McDonald TE, Margolis L (1995) Synopsis of parasites of Canada: supplement (1978-1993). Can Spec Publ Fish Aquat Sci 122:22-27

Mitchell LG, Seymour CL, Gamble JM (1985) Light and electron microscopy of Myxobolus hendricksoni sp. nov. (Myxozoa: Myxobolidae) infection the brain of the fathead minnow, Pimephales promelas Rafinesque. J Fish Dis 8: 75-89

Muzzall PM (1995) Parasites of pond-reared yellow perch from Michigan. Prog Fish-Cult 57:168-172

Nei M, Kumar S (2000) Molecular evolution and phylogenetics. Oxford University Press, New York, NY

Pote LM, Bellerud B, Lin TL, Chenney EF (1994) The isolation and propagation of Dero digitata infected with Aurantiactinomyxon sp. J Aquat Anim Health 25:303-307

Rommel F (2001) Mortalities due to parasites in yellow perch. Aquacult Mag March/April:27-30

Rzhetsky A, Nei M (1992) A simple method for estimating and testing minimum evolution trees. Mol Biol Evol 9:945-967

Saitou N, Nei M (1987) The neighbor-joining method: a new method for reconstructing phylogenetic trees. Mol Biol Evol 4:406-425

Sanger F, Nicklen S, Coulson AR (1977) DNA sequencing with chain-terminating inhibitors. Proc Natl Acad Sci USA 74:5463-5467

Tamura K, Nei M, Kumar S (2004) Prospects for inferring very large phylogenies by using the neighbor-joining method. Proc Natl Acad Sci USA 101:11030-11035

Tamura K, Dudley J, Nei M, Kumar S (2007) MEGA4: molecular evolutionary genetics analysis (MEGA) software, Version 4.0. Mol Biol Evol 24:1596-1599

Urawa S, Awakura T (1994) Protozoan diseases of freshwater fishes in Hokkaido. Sci Rep Hokkaido Fish Hatchery 48: 47-58

Yokoyama HK, Ohawa K, Wakabayashi H (1991) A new collection method of actinosporeans - a probable infective stage of myxosporeans to fishes from tubificids and experimental infection of goldfish with the actinosporean, Raabeia sp. Fish Pathol 26:133-138

Submitted: January 15, 2009; Accepted: November 11, 2009 Proofs received from author(s): February 12, 2010 